\title{
Evaluation of nitrogen fractionation in relation to physico- chemical properties of soil in Ambajogai Tahsil of Beed District
}

\author{
A. L. Dhamak ${ }^{1}$, N. A. Meshram* ${ }^{1}$ and S. L. Waikar ${ }^{1}$ \\ Department of Soil Science and Agricultural Chemistry, \\ VasantraoNaikMarathwadaKrishiVidyapeeth, Parbhani-431402, Maharashtra, India
}

\begin{abstract}
The study was conducted on Vertisols, Inceptisols and Entisols located in Ambajogai tahsil of Beed districtto evaluate the nitrogen fractionation in relation to physico-chemical properties of soil. For this purpose 125 representative soil samples were collected at 0.0-0.20 m depth from different villages of Ambajogai tahsil. These soil samples were analyzed for physico-chemical properties and status of available $P, K, S$, exchangeable Ca, Mg and nitrogen fractionation of soil. The soils under the study were neutral to alkaline in reaction, safe in limit of electrical conductivity and moderately calcareous to calcareous in nature. These soils were low to high in organic carbon content, whereas low in available $P$ and high in available $K$ of soil. While, the exchangeable Ca and available $S$ were in sufficient quantity, while exchangeable Mg ranged from low to high. Available $N$ was in low quantity, while total $N$ and other fractions almost in low quantity. The correlation analysis indicated that the $\mathrm{pH}$ and $\mathrm{CaCO}_{3}$ of soils showed negative and significant correlation with all the fractions of nitrogen, whereas organic carbon showed positive and significant correlation with different fractions of nitrogen. However, EC of soil did not established any relation with nitrogen fractions.
\end{abstract}

Key Words: Soil properties, calcium, magnesium, sulphur, nitrogen fractionation.

\section{Introduction}

The management of indigenous $\mathrm{N}$ is important issue in semiarid Agro-ecosystem Zone, because of $\mathrm{N}$ mineralization from soil organic matter (SOM) provides substantial portion of the total $\mathrm{N}$ uptake by different agricultural crops. The accumulation of nitrogen forms in soil is very common in Agricultural crop production systems.Nitrogen in soils occurs both in organic and inorganic forms. Organic forms of nitrogen constitutes of $95 \%$ or more of total nitrogen in surface soil and only 2 to $5 \%$ of nitrogen is present in inorganic form. The inorganic form is liable to be lost through different types of losses like runoff, ammonia volatilization, leaching, denitrification and fixation by clay minerals. The organic form of $\mathrm{N}$ particularly the hydrolysable form, is slowly mineralized and is transformed to mineral nitrogen through aminization, ammonification and nitrification processes and is made available to crops (More and Ghangale, 1992).Nitrogen is a basic element of all living cells. It is required in a chlorophyll, amino acids and protein synthesis. Nitrogen is present in the lithosphere, atmosphere, biosphere and hydrosphere. It plays an important role in increasing agricultural production. As a constituent of protein, it increases the food value. It also influenced the quality of environment.The inorganic form mainly includes ammonium $\left(\mathrm{NH}_{4}-\mathrm{N}\right)$ and nitrate-nitrogen $\left(\mathrm{NO}_{3}-\mathrm{N}\right)$ and it isnegatively charged and as such, it does not bind to the soilexchange site very firmly but rather held in the soil solutionwhich makes it being easily leached from the upper soil horizon by rainfall down to the rooting zone (Egbuchua, 2013). While, organic soil nitrogen occurs as proteins, amino acids, amino sugars and other nitrogenous compounds. The inorganic forms of $\mathrm{N}$ are always in a state of dynamic change and hence their contents in soil are highly variable. They may also be immobilized into inorganic forms through microbial assimilation, yet at the same time they may produce as a result of microbial disintegration of soil organic nitrogenous compounds. For these reason, the study we undertook on nitrogen fractions and their relation with soil properties in different villages of Ambajogai tehsil of Beed District under semiarid regionof Maharashtra.

\section{Materials And Methods}

The study area belongs to Ambajogai Tahsil of Beed district is located between $18^{0} 28^{\prime}$ to $19^{\circ} 28^{\prime}$ North altitude and $74^{\circ} 54^{\prime}$ to $76^{\circ} 57^{\prime}$ East latitude. The geographical area of the district is 10615.3 sq. $\mathrm{km}$ and it is 3.44 per cent of Maharashtra state. The annual rainfall of this district is in between $458 \mathrm{~mm}$ and $814 \mathrm{~mm}$. The maximum and minimum temperature of this district is $40.40^{\circ} \mathrm{C}$ and $17.68^{\circ} \mathrm{C}$, respectively. The elevation is 530 $\mathrm{m}$ from mean sea level. Beed is located on the Deccan Plateau, on the banks of 'Bendsura` a sub-tributary of Godavari River. The soils are developed on basaltic and metamorphic rocks of varying age and also on alluvium derived from such rocks. The study area comes under zone of assured rainfall zone where tropical climatic conditions often exists(Hot Dry Subhumid Agroecological Region).In order to studies on nitrogen fractionationfrom different villages of Ambajogai Tahsil of Beed District, one hundred and twenty five, representative surface $(0-0.20 \mathrm{~m})$ soil samples were collected, passed through $2 \mathrm{~mm}$ sieve and stored in properly 
labeled plastic bags. The soil pH, EC, Organic Carbon, available K, Exchangeable Ca and Mg were estimated by the standard procedures as described by Jackson (1973). The available $\mathrm{N}$ was analyzed by using alkaline potassium permanganate (Subbaiah and Asija, 1956). Available sulphur was determined by using $0.15 \% \mathrm{CaCl}_{2}$ solution(Williams and Steinberg, 1969). Total nitrogen was determined by Kjeldhal method (Page et al., 1989) and their forms were estimated (Bremner, 1965). Thewhole data was subjected to statistical analysis by the method described by Panse and Sukhatme (1985).

\section{Chemical properties}

\section{Result And Disscussion}

The entire data of soilsare classified into various soil orders as Vertisols, Inceptisols and Entisols (Table 1). The results revealed that, the $\mathrm{pH}$ value of Vertisols, Inceptisols and Entisols varied from 6.3 to 8.5, 6.7 to 8.8 and 6.8 to 8.6 respectively, which indicated that these soils are neutral to alkaline in reaction, whereas EC of Vertisols, Inceptisols and Entisols were ranged from 0.10 to $0.51,0.10$ to 0.85 and 0.10 to $0.37 \mathrm{dSm}^{-}$ ${ }^{1}$ respectively, which were categorized as normal. It may be due to formation of these soils from basaltic parent material rich in basic cations. Similar findings were reported by Jibhakateet al. (2009). The organic carbon in Vertisols, Inceptisols and Entisols ranged from 1.30 to $18.90,1.40$ to 16.00 and 1.40 to $11.40 \mathrm{~g} \mathrm{~kg}^{-1}$ with a mean value $5.00,4.50$ and $3.80 \mathrm{~g} \mathrm{~kg}^{-1}$. The majority of the soils of organic carbon range from low to high in different orders. This might be due to increased rate of decomposition of organic matter as concluded by Rashmiet al. (2009).However, the $\mathrm{CaCO}_{3}$ content in Vertisols, Inceptisols and Entisols varied between 36.00 to 155.00, 37.00 to 149.00 and 38.00 to $114.00 \mathrm{~g} \mathrm{~kg}^{-1}$ with a mean value $95.50,92.90,80.80 \mathrm{~g} \mathrm{~kg}^{-1}$, respectively. The majority of soils were categorized as calcareous in nature.This showed that most of the soil samples are calcareous in nature. Relative more accumulation of $\mathrm{CaCO}_{3}$ in Vertisols and associated black soils may be partly associated with their recent origin with rich in alkali earth and partly due to calcification process prevalent in this region (Mahesh kumar, 2011).The available P in Vertisols, Inceptisols and Entisols were ranged from 1.04 to 21.52, 1.04 to 21.27 and 1.46 to $25.09 \mathrm{~kg} \mathrm{ha}^{-1}$ with a mean value $11.28,11.14,14.0 \mathrm{~kg} \mathrm{ha}^{-1}$, respectively.The majority of soil samples were categorized as low in phosphorus content indicates the presence of calcareous types of parent materials. According to Turet al. (2008), the low amount of available P may be due to application of lower doses of $\mathrm{P}$ fertilizer, fixation of $\mathrm{P}$ on clay minerals or $\mathrm{CaCO}_{3}$ surfaces with the time elapsed between fertilizer application and crop uptake. The available $\mathrm{K}$ values of Vertisols, Inceptisols and Entisols varied from 118.50 to $840.30,127.7$ to 716.30 and 132.40 to $835.60 \mathrm{~kg} \mathrm{ha}^{-1}$ with an average of $538.60,485.80,550.20 \mathrm{~kg} \mathrm{ha}$ ${ }^{1}$, respectively. The maximum soils of above order were categorized as high potassium content.This may be due to occurrence of potash rich minerals like mica and feldspar in parent material of the soils (Turet al.,2008). The exchangeable Ca content in Vertisols, Inceptisols and Entisols were ranged from 11.50 to 50.70, 13.50 to 48.70 and 15.30 to $49.60 \mathrm{cmol}\left(\mathrm{P}^{+}\right) \mathrm{kg}^{-1}$ with a mean value $34.90,32.60,35.33 \mathrm{cmol}\left(\mathrm{P}^{+}\right) \mathrm{kg}^{-1}$, respectively. All the soil samples were categorized as high exchangeable $\mathrm{Ca}$ content. The exchangeable $\mathrm{Mg}$ in Vertisols, Inceptisols and Entisols were ranged from 7.80 to $28.60,7.60$ to 28.30 and 7.60 to $27.80 \mathrm{cmol}\left(\mathrm{P}^{+}\right) \mathrm{kg}^{-1}$ with an average of $18.30,15.70,17.60 \mathrm{cmol}\left(\mathrm{P}^{+}\right) \mathrm{kg}^{-1}$, respectively. The exchangeable $\mathrm{Mg}$ in three orders ranges from low to high. The available $S$ in Vertisols, Inceptisols and Entisols varied from 7.80 to $77.01,3.92$ to 76.31 and 4.22 to 53.28 $\mathrm{mg} \mathrm{kg}^{-1}$, respectively. Almost all the soil sample contains high available S. The available $\mathrm{S}$ appears to be depending on the combined action of factors like nature of parent material, rain fall, clay and organic matter content in soil (Mohamed Saqeebulla et al.,2012).

\section{Nitrogen fractionation}

Among the different nitrogen fractions (Table 2), the total nitrogen in the soils of Ambajogai tahsil were ranged from 0.060 to $0.096,0.032$ to 0.090 and 0.028 to 0.090 per cent with a mean value $0.108,0.061$, 0.059 per cent in Vertisols, Inceptisols and Entisols, respectively. The available $\mathrm{N}$ in Vertisols, Inceptisols and Entisols ranged from 108.70 to $487.10,109.70$ to 528.00 and 102.60 to $293.80 \mathrm{~kg} \mathrm{ha}^{-1}$ with an average of $296.92,318.91,198.23 \mathrm{~kg} \mathrm{ha}^{-1}$, respectively. The $\mathrm{N}$ content in above order varied from very low to high. Maximum soil samples categorized as low nitrogen content. Total hydrolysable $\mathrm{N}$ in the soils of Ambajogai tahsil were ranged from 495.00 to $720.00,240.00$ to 675.00 and 210.00 to $393.70 \mathrm{mg} \mathrm{kg}^{-1}$ with a mean value $607.50,457.50,393.70 \mathrm{mg} \mathrm{kg}^{-1}$ in Vertisols, Inceptisols and Entisols, respectively. Amino acid $\mathrm{N}$ in the soils of Ambajogai tahsil were ranged from 231.00 to $336.00,112.00$ to 315.00 and 98.00 to $269.50 \mathrm{mg} \mathrm{kg}^{-1}$ with an average of 283.50, 213.50, $183.70 \mathrm{mg} \mathrm{kg}^{-1}$ in Vertisols, Inceptisols and Entisols, respectively. Acid insoluble $\mathrm{N}$ in Vertisols, Inceptisols and Entisols were ranged from 105.00 to 505.50, 75.00 to 220.00 and 70.00 to 192.50 $\mathrm{mg} \mathrm{kg}^{-1}$ with a mean value $305.20,147.50,131.20 \mathrm{mg} \mathrm{kg}^{-1}$, respectively. The ammonical nitrogen inVertisols, Inceptisols and Entisols were ranged from 23.76 to $34.56,11.50$ to 32.40 and 10.08 to $32.40 \mathrm{mg} \mathrm{kg}^{-1}$ with a mean value 29.16, 21.96 and $21.24 \mathrm{mg} \mathrm{kg}^{-1}$, respectively. Nitrate nitrogen in the soils of Ambajogai tahsil were ranged from 9.9 to $14.10,4.80$ to 13.50 and 4.20 to $13.50 \mathrm{mg} \mathrm{kg}^{-1}$ with a mean value of $12.00,9.15$ and $8.85 \mathrm{mg}$ $\mathrm{kg}^{-1}$, in Vertisols, Inceptisols and Entisols, respectively.Relatively higher total nitrogen content in vertisols may 
be due to high clay content and lower values of total nitrogen in Inceptisols and Entisols may be associated partly with different parent material and its rate of disintegration (Ghatol and Malewar, 1978). Similar results also reported by Das et al. (2006) and Tabassum et al., (2010). Vertisols showed higher mean values for total hydrolysable, amino acid, acid insoluble, ammonical and nitrate nitrogen as compared to Inceptisols and Entisols which is partly attributed to higher content of total $\mathrm{N}$ in these soils as compared to other soil groups. Further higher values of various fractions of nitrogen in Vertisols and Inceptisols may be associated with finer texture of soil and high organic carbon content (Walia et al., 1998; Singh and Singh, 2007).

\section{Correlationcoefficient}

The data on correlation coefficient study between physico-chemical properties and different fractions of nitrogen in Vertisols (Table 3) observed that, total nitrogen was significantly affected by $\mathrm{pH}$, organic carbon and $\mathrm{CaCO}_{3}$ content. It could not established any relationship with electrical conductivity, whereas $\mathrm{pH}$ and $\mathrm{CaCO}_{3}$ showed negative relationship with total nitrogen content which is evident by ' $\mathrm{r}$ ' value- $0.313^{*}$ and $0.396^{* *}$, respectively. Further, it was indicated that organic carbon was positively and significantly correlated with total nitrogen which is expressed by ' $r$ ' $\left(0.315^{*}\right)$ values. The $\mathrm{pH}$ and $\mathrm{CaCO}_{3}$ of soils showed negative relationship with available nitrogen content, whereas organic carbon was associated positively with available nitrogen which was evident by' $r$ ' values for $\mathrm{pH}(-0.283 *), \mathrm{CaCO}_{3}\left(-0.300^{*}\right)$ and organic carbon $\left(0.295^{*}\right)$. However, the effect of electrical conductivity did not reach to the level of significance. The various fractions of nitrogen also found to be influenced by physico-chemical properties of soil. Soils $\mathrm{pH}$ and $\mathrm{CaCO}_{3}$ were found to bear negative relationship with total hydrolysable, amino acid, acid insoluble, ammonical and nitrate fractions of nitrogen, whereas organic carbon showed positive relationship with these fractions of nitrogen. Negative ' $r$ ' values of $\left(-0.318^{*},-0.286^{*},-0.308^{*},-0.304^{*},-0.311^{*}\right.$ and $\left.-0.371^{* *},-0.396^{* *},-0.343^{*},-0.339,-0.281^{*}\right)$ were noticed in between $\mathrm{pH}$ and total hydrolysable, amino acid, acid insoluble, ammonical and nitrate nitrogen and in between $\mathrm{CaCO}_{3}$ and total hydrolysable, amino acid, acid insoluble, ammonical and nitrate nitrogen respectively. Significant positive relationship with organic carbon was evident from ' $r$ ' values for total hydrolysable $\left(0.307^{*}\right)$ amino acid $\left(0.328^{*}\right)$, acid insoluble $\left(0.357^{* *}\right)$, ammonical $\left(0.321^{*}\right)$ and nitrate $\left(0.291^{*}\right)$ fractions of nitrogen. However electrical conductivity showed no significant relation with other fractions of nitrogen.

The data on correlation coefficient between physico-chemical properties and nitrogen fractions in Inceptisols (Table 4), resulted that the $\mathrm{pH}$ and $\mathrm{CaCO}_{3}$ of soils were showed significant and negative correlation with total nitrogen which is evident by ' $r$ ' values of $-0.296^{*}$ and $-0.309^{*}$, respectively. Further, it was noticed that organic carbon was positively and significantly correlated with total nitrogen which is indicated by ' $r$ ' $\left(0.289^{*}\right)$ values. Electrical conductivity of Inceptisols did not show any correlation with total nitrogen.However, $\mathrm{pH}$ and $\mathrm{CaCO}_{3}$ showed negative relationship with available nitrogen content, whereas organic carbon showed positive and significant correlation with available nitrogen which was evident by ' $\mathrm{r}$ ' values for $\mathrm{pH}(-0.284 *)$, $\mathrm{CaCO}_{3}\left(-0.286^{*}\right)$ and organic carbon $\left(0.313^{*}\right)$. However electrical conductivity could not established any relation with available nitrogen. The various fractions of nitrogen also found to be influenced by physicochemical properties of Inceptisols. Significant negative relationship with $\mathrm{pH}$ and $\mathrm{CaCO}_{3}$ was evident from ' $\mathrm{r}$ ' values of $\left(-0.296^{*},-0.322^{*},-0.339^{*},-0.296^{*},-0.308^{*}\right.$ and $-0.309^{*},-0.286^{*},-0.309^{*},-0.313^{*},-0.364^{*},-$ $\left.0.309^{*},-0.315^{*}\right)$ were observed in between $\mathrm{pH}$ and total hydrolysable, amino acid, acid insoluble, ammonical and nitrate fractions of nitrogen and in between $\mathrm{CaCO}_{3}$ and total hydrolysable, amino acid, acid insoluble, ammonical and nitrate nitrogen, respectively. In case of electrical conductivity, it did not reach to the level of significance with all the fractions of nitrogen. However, organic carbon showed significant positive relationship was evident from ' $r$ ' values for total hydrolysable $\left(0.369^{*}\right)$, amino acid $\left(0.348^{*}\right)$, acid insoluble $\left(0.304^{*}\right)$, ammonical $\left(0.299^{*}\right)$ and nitrate nitrogen $\left(0.285^{*}\right)$.

The results on correlation coefficient between physico-chemical properties and nitrogen fractions in Entisols (Table 5) emerged out indicated that, the $\mathrm{pH}$ and $\mathrm{CaCO}_{3}$ showed negative and significant correlation with total nitrogen which is evident by ' $\mathrm{r}$ ' values of $-0.352 *$ and $-0.361 *$ respectively, whereas electrical conductivity of Entisols did not show any relation with total nitrogen. However, it was noticed that organic carbon was significantly and positively correlated with total nitrogen which is indicated by ' $\mathrm{r}$ ' $\left(0.363^{*}\right)$ values.Soils $\mathrm{pH}$ and $\mathrm{CaCO}_{3}$ showed negative relationship with available nitrogen content. Whereas,organic carbon related positively correlated with available nitrogen which was evident by ' $\mathrm{r}$ ' values for $\mathrm{pH}\left(-0.334^{*}\right)$, $\mathrm{CaCO}_{3}(-0.382 *)$ and organic carbon $(0.463 * *)$. Further, the effect of electrical conductivity did not reach to the level of significance.The various fractions of nitrogen were also influenced by physico-chemical properties of soil. The $\mathrm{pH}$ and $\mathrm{CaCO}_{3}$ of soils were found to bear negative relationship with total hydrolysable, amino acid, acid insoluble, ammonical and nitrate fractions of nitrogen, whereas, organic carbon showed positive relationship with these fractions of nitrogen. Negative ' $r$ ' values of $\left(-0.343^{*},-0.343^{*},-0.341^{*}, 0.344^{*},-0.383^{*}\right.$ and $\left.-0.418^{* *},-0.363^{*},-0.307^{*},-0.360^{*},-0.407^{*}\right)$ were observed in between $\mathrm{pH}$ and total hydrolysable, amino acid, acid insoluble, ammonical and nitrate nitrogen and in between $\mathrm{CaCO}_{3}$ and total hydrolysable, amino acid, 
acid insoluble, ammonical and nitrate nitrogen respectively. Positive and significant relationship with organic carbon was evident from ' $r$ ' values for total hydrolysable $\left(0.308^{*}\right)$, amino acid $\left(0.370^{*}\right)$, acid insoluble $\left(0.369^{*}\right)$, ammonical $\left(0.362^{*}\right)$ and nitrate $\left(0.369^{*}\right)$ fractions of nitrogen. However electrical conductivity did not reach to the level of significance with all the fractions of nitrogen in Entisols. It was depicted from the table No. 19, 20 and 21 that increasing contents of organic carbon in soils resulted in increase in availability of nitrogen fractions indicated by ' $r$ ' values. Availability of nitrogen fractions in presence of higher content of organic carbon is due to which are known to promote the availability and solubility of nitrogen (Laxminarayana, 2006) and Tabassum et al., 2010). Negative and significant correlation between nitrogen fractions and $\mathrm{pH}$ were observed. High $\mathrm{pH}$ of soil decreases the pool of total and available nitrogen in soil. Similarly negative relationship between $\mathrm{CaCO}_{3}$ and nitrogen fractions attributed that calcium carbonate might have acted as a strong absorbent of nitrogen fractions resulted in low solubility in soil (Kaistha et al., 1990).

\section{Conclusion}

The soils of study areas are classified into Vertisols, Inceptisols and Entisols. Most of the soil sample $\mathrm{pH}$ was alkaline in nature and $\mathrm{EC}$ of the soil was in safe limit for the crop growth. The organic carbon status was low to high and calcareous in nature. Low phosphorus and high potassium were observed in this soil. The exchangeable $\mathrm{Ca}$ and available $\mathrm{S}$ were in sufficient quantity, while exchangeable $\mathrm{Mg}$ ranged from low to high. Available nitrogen was in low quantity, while total nitrogen and other fractions also in low quantityand could be attributed to excessive leaching of this highly mobile and negatively charged ion. Other nutrient elements investigated in the study were found to occur in low to moderate status or levels. In Vertisols, Inceptisols and Entisols, all the nitrogen fractions showed negative and significant correlated with $\mathrm{pH}$ and $\mathrm{CaCO}_{3}$ while organic carbon positively correlated with nitrogen fractions.

References

[1]. Bremner, J. M. (1965) Inorganic forms of nitrogen In : Methods of Soil Analysis, part II. Agronomy, America Society of Agronomy, Inc. Medison, Wisconsin.

[2]. Das, Indranil, Ghosh Koushik, Ray, S. C., Mukhopadhay, P.K. and Ghosh, S.K. (2006) Status and distribution of Sulphur vis-à-vis taxonomic classwise distribution of sulphur in selected soil series of Inceptisols in West Bengal. Journal of the Indian Society of Soil Science, 41: 776-777.

[3]. Egbuchua, C. N. (2013) Nitrate-nitrogen and related nutrient contents of some alluvial vegetable production system in Delta State, Nigeria. International Journal of Science and Nature, $4: 420-424$.

[4]. Ghatol, S. G. and Malewar, G. U. (1978) Influence of texture and organic matter on the physical properties of Marathwada soils. Research Bulletin, Marathwada Agricultural University, 2 : 10-11.

[5]. Jackson, M .L. (1973) Soil Chemical Analysis, Prentice Hall of India Private Ltd. New Delhi.

[6]. Jibhakate, S.B., Bhende, S.N., Kharche, V.K. and Sevalakshmi, V. (2009) Physico-chemical status of soils of Katol tahasil in Nagpur District. Journal of Soils and Crops, $19: 122-128$.

[7]. Kaistha, B.P. Sood, R.D. and Kanwar, B.S. (1990) Distribution of nitrogen in some forest soil profiles of North- Western Himalayan region. Journal of the Indian Society of Soil Science, 38 : 15-20.

[8]. Laxminarayana, K. (2006) Evaluation of available nitrogen indices for Rice in soils of Mizoram. Journal of the Indian Society of Soil Science, $\mathbf{5 4}: 332-336$.

[9]. Mahesh kumar, Singh, S.K., Raina, P. and Sharma, B.K. (2011)Status of available major and micronutrients in arid soils of Churu district of Western Rajasthan. Journal of Indian Society of Soil Science, 59 : 188-192.

[10]. Mohamed Saqueeblla, H., Gurumurthy, K.T. and Prakasha, H.C. (2012)Physico-chemical properties of soils under different land use systems. Mysore Journal of Agricultural Sciences, $46: 99-105$.

[11]. More, S.B. and Ghangale, D.P. (1992) Soil N balance in wheat as influenced by preceeding Kharif pulse crops. Journal Maharashtra Agricultural University, $17: 473-474$.

[12]. Page, A.L., Honda, C. and Krik, P.L. (1989) Methods of Chemical Analysis, part-2. pp. 600-603.

[13]. Panse, V.G. and Sukhatme, P.V. (1985) Statistical Methods for Agricultural Workers, ICAR, New Delhi.

[14]. Rashmi, I., Dasog, G.S., Bhanuprakash, U.H. and Lalitha Humne, (2009)Physico-chemical properties of paddy growing soils of upper Krishna project in Karnataka. Journal of Soils and Crops, $19: 49-53$.

[15]. Singh, K.K. and Singh, R. (2007) Distribution of nitrogen and sulphur forms in soil profiles of Mid- Western Uttar Pradesh. Journal of the Indian Society of Soil Science, $55: 478-480$.

[16]. Subbiah, B.V. and Asija, G.L. (1956) Rapid procedure for the estimation of available nitrogen in soil. Currunt Science, 25 : 259260.

[17]. Tabassum, shahina, Sammy Reddy, Muneshwar Singh and Biswas, A.K. (2010) changes in organic and inorganic forms of nitrogen in a typic haplustert under soybean- wheat system due to conjoint use of inorganic fertilizers and organic manures. Journal of the Indian Society of Soil Science, $58: 76-85$.

[18]. Tur, N.S., Meenakshi, Sharma, P.K., Anil Sood, Setia, R.K., Harpinder Singh and Nayyar, V.K. (2008)Mapping of macronutrient status and multi macronutrient deficiency in Patiala district using frontier technologies; Journal of Soils and Crops, 18 : 1-6.

[19]. Walia, S., Uppal, K.S. and Rao, Y.S. (1998) Profile distribution of various forms of nitrogen in some land forms of Bundelkhand region of Uttar Pradesh. Journal of the Indian Society of Soil Science,46 : 193-198.

[20]. Williams, C.H. and Steinbergs, A. (1959) Soil sulphur fraction as chemical indices of available sulphur in some Australian soils. Australian Journal of Agricultural Research,10 : 340-350. 
Evaluation of nitrogen fractionation in relation to physico-chemical properties of soil in ....

Table 1. Range and average value of soil site characteristics

\begin{tabular}{|c|c|c|c|c|c|c|c|c|c|}
\hline Soil order & pH & $\begin{array}{c}\mathrm{EC} \\
\left(\mathrm{dSm}^{-1}\right)\end{array}$ & $\begin{array}{l}\text { O.C. } \\
(\%)\end{array}$ & $\begin{array}{c}\mathrm{CaCO}_{3} \\
(\%)\end{array}$ & $\begin{array}{c}\mathbf{P}_{2} \mathrm{O}_{5} \\
\left(\mathrm{~kg} \mathrm{ha}^{-1}\right)\end{array}$ & $\begin{array}{c}\mathrm{K}_{2} \mathrm{O} \\
\left(\mathrm{kgha}^{-1}\right)\end{array}$ & $\begin{array}{c}\mathrm{Ca} \\
(\mathrm{cmol} \\
\left.\left(\mathbf{p}^{+}\right) \mathrm{kg}^{-1}\right)\end{array}$ & $\begin{array}{l}\mathrm{Mg}(\mathrm{cmol} \\
\left.\left(\mathbf{p}^{+}\right) \mathrm{kg}^{-1}\right)\end{array}$ & $\begin{array}{c}\text { Avai. } \\
\text { sulphur } \\
\left(\mathrm{mgkg}^{-1}\right)\end{array}$ \\
\hline Vertisol & $\begin{array}{c}6.3-8.5 \\
(8.20)\end{array}$ & $\begin{array}{c}0.10-0.51 \\
(0.27)\end{array}$ & $\begin{array}{c}1.30- \\
18.9 \\
(5.00)\end{array}$ & $\begin{array}{c}36.0-155 \\
(95.50)\end{array}$ & $\begin{array}{c}1.04-21.52 \\
(11.28)\end{array}$ & $\begin{array}{c}118.50- \\
840.30 \\
(538.60)\end{array}$ & $\begin{array}{c}11.50-50.70 \\
(34.90)\end{array}$ & $\begin{array}{c}7.80-28.60 \\
(18.30)\end{array}$ & $\begin{array}{c}7.81-77.01 \\
(31.80)\end{array}$ \\
\hline Inceptisol & $\begin{array}{c}6.7-8.8 \\
(7.97)\end{array}$ & $\begin{array}{l}0.10-0.85 \\
\quad(0.23)\end{array}$ & $\begin{array}{c}1.40- \\
16.0 \\
(4.50)\end{array}$ & $\begin{array}{c}37.0-149 \\
(92.90)\end{array}$ & $\begin{array}{c}1.03-21.47 \\
(11.25)\end{array}$ & $\begin{array}{c}127.70- \\
716.30 \\
(485.80)\end{array}$ & $\begin{array}{c}13.50-48.70 \\
(32.60)\end{array}$ & $\begin{array}{c}7.60-28.30 \\
(15.70)\end{array}$ & $\begin{array}{c}3.92-76.31 \\
\quad(30.70)\end{array}$ \\
\hline Entisol & $\begin{array}{c}6.8-8.6 \\
(7.90)\end{array}$ & $\begin{array}{c}0.10-0.37 \\
(0.19)\end{array}$ & $\begin{array}{c}1.40- \\
11.4 \\
(3.80)\end{array}$ & $\begin{array}{c}38.0-114 \\
(80.80)\end{array}$ & $\begin{array}{c}1.65-26.08 \\
(14.00)\end{array}$ & $\begin{array}{c}132.40- \\
835.60 \\
(550.20)\end{array}$ & $\begin{array}{c}15.30-49.60 \\
(35.33)\end{array}$ & $\begin{array}{c}7.60-27.80 \\
(17.60)\end{array}$ & $\begin{array}{c}4.22-53.28 \\
\quad(25.70)\end{array}$ \\
\hline
\end{tabular}

Parenthesis “()"indicates average mean value

Table 2. Range and average value of nitrogen fractionation in soils

\begin{tabular}{|c|c|c|c|c|c|c|c|}
\hline Soil order & $\begin{array}{c}\text { Total N } \\
(\%)\end{array}$ & $\begin{array}{l}\text { Available N } \\
\left(\mathrm{kg} \mathrm{ha}^{-1}\right)\end{array}$ & $\begin{array}{c}\text { Total } \\
\text { hydrolysable } \mathrm{N} \\
\left(\mathrm{mg} \mathrm{kg}^{-1}\right)\end{array}$ & $\begin{array}{l}\text { Amino acid N } \\
\left(\mathrm{mg} \mathrm{kg}^{-1}\right)\end{array}$ & $\begin{array}{l}\text { Acid insoluble } \\
\text { N }\left(\mathrm{mg} \mathrm{kg}^{-1}\right)\end{array}$ & $\underset{\left(\mathrm{mg} \mathrm{kg}^{-1)}\right.}{\operatorname{Ammonical} \mathbf{N}}$ & $\begin{array}{l}\text { NitrateN } \\
\left(\mathrm{mg} \mathrm{kg}^{-1)}\right.\end{array}$ \\
\hline Vertisols & $\begin{array}{c}0.060- \\
0.096 \\
(0.108)\end{array}$ & $\begin{array}{c}108.70- \\
484.10 \\
(296.92)\end{array}$ & $\begin{array}{c}495.00-720.00 \\
(607.50)\end{array}$ & $\begin{array}{c}231.00-336.00 \\
(283.50)\end{array}$ & $\begin{array}{l}105.00-505.50 \\
(305.25)\end{array}$ & $\begin{array}{c}23.76-34.56 \\
(29.16)\end{array}$ & $\begin{array}{l}9.90-14.10 \\
(12.00)\end{array}$ \\
\hline Inceptisols & $\begin{array}{c}0.030- \\
0.090 \\
(0.060)\end{array}$ & $\begin{array}{c}109.70- \\
528.00 \\
(318.90)\end{array}$ & $\begin{array}{c}240.00-675.00 \\
(475.50)\end{array}$ & $\begin{array}{c}112.00-315.00 \\
(213.50)\end{array}$ & $75-220(147.50)$ & $\begin{array}{c}11.50-32.40 \\
(21.96)\end{array}$ & $\begin{array}{l}4.80-13.50 \\
\quad(9.15)\end{array}$ \\
\hline Entisols & $\begin{array}{c}0.028- \\
0.090 \\
(0.059)\end{array}$ & $\begin{array}{c}102.60- \\
293.80 \\
(198.23) \\
\end{array}$ & $\begin{array}{l}210.00-577.50 \\
\quad(393.70)\end{array}$ & $\begin{array}{l}98.00-269.50 \\
(183.70)\end{array}$ & $\begin{array}{l}70.00-192.50 \\
(131.20)\end{array}$ & $\begin{array}{l}10.08-32.40 \\
(21.24)\end{array}$ & $\begin{array}{l}4.20-13.50 \\
\quad(8.85)\end{array}$ \\
\hline
\end{tabular}

Parenthesis "( )" indicates average mean value

Table 3. Correlation between chemical properties and nitrogen fractionation in Vertisols

\begin{tabular}{|c|c|c|c|c|c|c|c|c|}
\hline $\begin{array}{c}\text { Chemical } \\
\text { properties }\end{array}$ & Total N & Available N & $\begin{array}{c}\text { Total } \\
\text { hydrolysable }\end{array}$ & $\mathbf{N}$ & $\begin{array}{c}\text { Amino acid } \\
\mathbf{N}\end{array}$ & $\begin{array}{c}\text { Acid } \\
\text { Insoluble N } \\
\end{array}$ & Ammonical N & Nitrate $\mathbf{N}$ \\
\hline pH & $-0.313^{*}$ & $-0.283^{*}$ & $-0.318^{*}$ & & $-0.286^{*}$ & $-0.308^{*}$ & $-0.304 *$ & $-0.311 *$ \\
\hline EC & -0.241 & -0.034 & -0.263 & & -0.244 & -0.181 & -0.192 & -0.253 \\
\hline $\mathrm{CaCO}_{3}$ & $-0.396 * *$ & $-0.300 *$ & $-0.371 * *$ & & $-0.398 * *$ & $-0.343 *$ & $-0.339 *$ & $-0.281 *$ \\
\hline O.C & $0.315^{*}$ & $-0.295^{*}$ & $0.307^{*}$ & & $0.328^{*}$ & $0.357 * *$ & $0.321 *$ & $0.291 *$ \\
\hline
\end{tabular}

* Significant at $\mathrm{p}=0.05$ level: -0.273

** Significant at $\mathrm{p}=0.01$ level: -0.354

Table 4. Correlation between chemical properties and nitrogen fractionation in Inceptisol

\begin{tabular}{cccccccc}
\hline $\begin{array}{c}\text { Chemical } \\
\text { properties }\end{array}$ & Total N & Available N & $\begin{array}{c}\text { Total } \\
\text { hydrolysable }\end{array}$ & $\begin{array}{c}\text { Amino } \\
\text { acid N }\end{array}$ & $\begin{array}{c}\text { Acid } \\
\text { Insoluble N }\end{array}$ & Ammonical N & Nitrate N \\
\hline pH & $-0.296^{*}$ & $-0.284^{*}$ & $-0.296^{*}$ & $-0.322^{*}$ & $-0.339^{*}$ & $-0.296^{*}$ \\
EC & -0.161 & -0.160 & -0.161 & -0.171 & -0.242 & -0.161 & -0.173 \\
$\mathbf{C a C O}_{3}$ & $-0.309^{*}$ & $-0.286^{*}$ & $0.309 *$ & $-0.313^{*}$ & $-0.364^{*}$ & $-0.309^{*}$ & $-0.315^{*}$ \\
$\mathbf{O . C}$ & $0.289^{*}$ & $0.313^{*}$ & $0.369^{* *}$ & $0.348^{*}$ & $0.304^{*}$ & $0.299^{*}$ & $0.285^{*}$ \\
\hline
\end{tabular}

* Significant at $\mathrm{p}=0.05$ level: -0.273

** Significant at $\mathrm{p}=0.01$ level: -0.354

Table5. Correlation between chemical properties and nitrogen fractionation in Entisols

\begin{tabular}{|c|c|c|c|c|c|c|c|c|}
\hline $\begin{array}{l}\text { Chemical } \\
\text { properties }\end{array}$ & Total N & Available N & $\begin{array}{c}\text { Total } \\
\text { hydrolysable }\end{array}$ & $\mathbf{N}$ & $\begin{array}{l}\text { Amino } \\
\operatorname{acid} \mathbf{N}\end{array}$ & $\begin{array}{c}\text { Acid } \\
\text { Insoluble N }\end{array}$ & Ammonical N & Nitrate $\mathbf{N}$ \\
\hline pH & $-0.352 *$ & $-0.334^{*}$ & $-0.343 *$ & & $-0.343^{*}$ & $-0.341^{*}$ & $-0.334^{*}$ & $-0.383^{*}$ \\
\hline EC & 0.107 & 0.134 & 0.136 & & 0.110 & 0.106 & 0.103 & 0.099 \\
\hline $\mathrm{CaCO}_{3}$ & $-0.361 *$ & $-0.382 *$ & $-0.418^{* *}$ & & $-0.363^{*}$ & $-0.307^{*}$ & $-0.360^{*}$ & $-0.407^{*}$ \\
\hline O.C & $0.363^{*}$ & $0.463 * *$ & $0.308 *$ & & $0.370 * *$ & $0.369 *$ & $0.362 *$ & $0.369 *$ \\
\hline
\end{tabular}

* Significant at $\mathrm{p}=0.05$ level: -0.325

** Significant at $\mathrm{p}=0.01$ level: -0.418 